\title{
RESEARCH
}

Open Access

\section{Urea cycle disorders in India: clinical course, biochemical and genetic investigations, and prenatal testing}

Sunita Bijarnia-Mahay ${ }^{1 *}$ (D), Johannes Häberle ${ }^{2}$, Anil B. Jalan ${ }^{3}$, Ratna Dua Puri ${ }^{1}$, Sudha Kohli ${ }^{1}, K^{2}$ etki Kudalkar ${ }^{3}$, Véronique Rüfenacht ${ }^{2}$, Deepti Gupta', Deepshikha Maurya', Jyotsna Verma', Yosuke Shigematsu4, Seiji Yamaguchi ${ }^{5}$, Renu Saxena ${ }^{1}$ and Ishwar C. Verma ${ }^{1}$

\begin{abstract}
Background: Urea cycle disorders (UCDs) are inherited metabolic disorders that present with hyperammonemia, and cause significant mortality and morbidity in infants and children. These disorders are not well reported in the Indian population, due to lack of a thorough study of the clinical and molecular profile.

Results: We present data from two major metabolic centres in India, including 123 cases of various UCDs. The majority of them $(72 / 123,58 \%)$ presented in the neonatal period (before 30 days of age) with $88 \%$ on or before day 7 of life (classical presentation), and had a high mortality (64/72, 88\%). Citrullinemia type 1 was the most common UCD, observed in 61/123 patients. Ornithine transcarbamylase (OTC) deficiency was the next most common, seen in 24 cases. Argininosuccinic aciduria was diagnosed in 20 cases. Deficiencies of arginase, N-acetylglutamate synthase, carbamoyl phosphate synthetase, citrin, and lysinuric protein intolerance were also observed.

Molecular genetic analysis revealed two common ASS1 mutations: c.470G > A (p.Arg157His) and c.1168G > A (p.Gly390Arg) (36 of 55 tested patients). In addition, few recurrent point mutations in ASL gene, and a deletion of the whole OTC gene were also noted. A total of 24 novel mutations were observed in the various genes studied. We observed a poor clinical outcome with an overall all time mortality of 63\% (70/110 cases with a known follow-up), and disability in 70\% (28/40) among the survivors. Prenatal diagnosis was performed in 30 pregnancies in 25 families, including one pre-implantation genetic diagnosis.

Conclusions: We report the occurrence of UCDs in India and the spectrum that may be different from the rest of the world. Citrullinemia type 1 was the most common UCD observed in the cohort. Increasing awareness amongst clinicians will improve outcomes through early diagnosis and timely treatment. Genetic diagnosis in the proband will enable prenatal/pre-implantation diagnosis in subsequent pregnancies.
\end{abstract}

Keywords: Urea cycle, UCD, OTC deficiency, Citrullinemia, Argininosuccinic aciduria, Mutation, Prenatal diagnosis, Hyperammonemia

\footnotetext{
*Correspondence: Bijarnia@gmail.com; sunitabijarnia@sgrh.com

'Institute of Medical Genetics and Genomics, Sir Ganga Ram Hospital, New

Delhi, India

Full list of author information is available at the end of the article
}

(c) The Author(s). 2018 Open Access This article is distributed under the terms of the Creative Commons Attribution 4.0 International License (http://creativecommons.org/licenses/by/4.0/), which permits unrestricted use, distribution, and reproduction in any medium, provided you give appropriate credit to the original author(s) and the source, provide a link to the Creative Commons license, and indicate if changes were made. The Creative Commons Public Domain Dedication waiver (http://creativecommons.org/publicdomain/zero/1.0/) applies to the data made available in this article, unless otherwise stated. 


\section{Background}

Urea Cycle Disorders (UCD) are a group of inborn errors of metabolism seen frequently in tertiary care intensive care units (ICUs) in view of the hyperammonemic encephalopathy which is the most common presenting feature. The overall incidence of UCD varies from 1:8000 to 1:44,000 births [1-4]. A more recent study from 3 countries in Europe reported an estimated cumulative incidence of 1 in 51,946 for UCDs [5]. Incidence of UCD is not known in India. All types of UCDs have been recognized.

The overall outcome of children with UCD remains poor, even in the developed world where excellent infrastructure and facilities are available $[1,6]$. Children with UCD are recognized after symptoms of hyperammonemia such as lethargy and coma occur, thus leading to a significant delay in diagnosis. This may happen in babies who are screened as well, because neonatal hyperammonemic encephalopathy often occur before neonatal screening test results are known. A delay in diagnosis results in either death or neurodisability $[7,8]$. This is exacerbated by a lack of awareness amongst families and primary health care physicians, causing a delay in seeking medical attention. Additional factors in developing countries like India are inadequate facilities in most primary and secondary level hospitals that contribute to a poor outcome. For instance, laboratory ammonia assays are usually only available even in tertiary hospitals. Therefore, a majority of babies die without a diagnosis, or are recognized very late, contributing to increased morbidity and mortality. An accurate genetic diagnosis is essential not only for appropriate management of the child, but also for genetic counseling in the context of subsequent pregnancies and carrier testing. So far, only a few mutations have been reported from India [9-12]. The Indian population is a unique mix of several cultures and sects, with considerable consanguinity. With the distinctness of Indian gene pool, mutations may be different from other populations and perhaps recurrent in some areas in view of closed community marriages, limiting the gene pool to an ethnic group.

We present here our experience in diagnosis, genetic testing and outcome after diagnosis of UCD in these families. The data was collected from two major metabolic centres in India.

\section{Methods}

\section{Patient cohort}

All neonates and children presenting with hyperammonemia and biochemical/clinical features of UCD since year 2001 till December 2017 were included in the cohort. The patients were collected from two centres. In the first centre at Sir Ganga Ram Hospital, New Delhi, they were chosen either from the genetic clinic or from the molecular genetics laboratory, which received samples for genetic testing for UCD from referring clinicians. A biochemical diagnosis of UCD was taken as the inclusion criteria. In some cases, where DNA of the index patient was not available, parents of the deceased patients were enrolled in the study, where good clinical and biochemical data was available to fulfill the diagnostic criteria. This centre was designated as Centre 1. In addition, cases from another referral centre (Centre 2) in Mumbai (NIRMAN) were also included in this study. All cases with complete clinical, biochemical and molecular genetic data were taken. All parents or legal guardians provided their consent for DNA testing. All the tests were carried out as part of clinical care as diagnostically indicated.

For selection of cases, information of clinical symptoms and hyperammonemia were solicited. This was followed by biochemical analysis of amino acids by Tandem mass spectrometry (MS/MS) on dried blood spots (DBS) or Ultra/ High performance liquid chromatography (U/HPLC) on plasma samples, and quantification of urinary orotic acid by Gas chromatography-mass spectrometry (GC-MS). To confirm the diagnosis of UCD, genetic testing was carried out on DNA extracted from peripheral blood or dried blood spots from affected children or their parents, where the index case's sample was not available. Sequencing of the genes was performed either at Münster University in Germany (2001-2008) or University Children's Hospital in Zurich (2008-2017) or at Sir Ganga Ram Hospital (2008-2017) in New Delhi. Genetic testing was done in cases from both centres. Prenatal diagnosis using chorionic villous sampling (CVS) or amniocentesis and mutation analysis was performed in subsequent pregnancies of families.

\section{Molecular studies for UCD gene mutations}

DNA was isolated from human samples using standard methods. PCR products were purified using Multiscreen ${ }^{\mathrm{R}}$ $\mathrm{PCR}_{\mu 96}$ plate (MilliPore, USA). Bidirectional sequencing of the coding exons and corresponding intron/exon boundaries were set up using the same primers as for PCR, with purified PCR products using BigDye ${ }^{\odot}$ Terminator v 3.1 cycle sequencing kit (Applied Biosystems, California). Sequencing was carried out on ABI 3500Dx automated sequencer unit (Applied Biosystems). Sequence chromatograms obtained were analyzed with Chromas software (Technelysium, Tewantin, Australia) and by manual inspection.

Obtained sequences were compared by blasting them against the reference genomic sequences (for ASS1: NM_000050, NP000041; for ASL: NM_000048, NP_000039; for OTC: NM_000531, NP_000522). Bioinformatics analysis was carried out to determine the functional consequences of mutations and their effects on protein structure by using different tools, e.g., Polyphen2 (genetics.bwh.harvard.edu/pph2/), Mutation Taster (www.mutationtaster.org/), or Sorting Intolerant from Tolerant (http:// provean.jcvi.org/index.php) [13-15]. 
The probands with suspected OTC deficiency or their mothers (in case of non-availability of DNA from proband due to death prior to diagnosis), were evaluated for deletions/duplications in the OTC gene by (Multiplex ligation probe amplification) MLPA probe mix (MRC Holland P079-OTC). Mutation analyses at Münster or Zurich University were done as reported [16-19].

For one patient, cDNA analysis of CPS1 gene was performed. RNA-isolation and CDNA-synthesis was performed using an established protocol [20]. Amplification by PCR and direct sequencing of the carbamoylphosphate synthetase 1 transcript was done in 6 overlapping fragments. Ref. sequences: GenBank NM_001875.4 and Ensembl ENSG00000021826, ENST00000233072.

\section{Results}

A total of 148 patients from the two centres were collected, of whom 123 patients from 123 families fulfilled the criteria and were included in the study. Nine patients from Centre 1 , and 16 cases from Centre 2 were excluded because of lack of a confirmed diagnosis. Seventy seven cases from Centre 1 and 48 from Centre 2 fulfilled the criteria and were enrolled. In the cohort of patients whose data was collected, $82 \%$ have been after year 2007.

The diagnosis was established in all 123 patients; 61 had citrullinemia type 1, 26 patients had OTC deficiency, 20 were of argininosuccinic aciduria (ASA), 9 had arginase deficiency, 3 had carbamoyl phosphate synthetase (CPS1), 2 had N-acetyl glutamate synthase (NAGS) deficiency and one patient each had lysinuric protein intolerance (LPI) and citrin deficiency (Table 1). All patients were diagnosed biochemically by quantitative amino acid analysis on dried blood spots (MS/MS) or in plasma (U/HPLC), except for LPI where both plasma and urine amino acid quantitation was performed by HPLC (see Additional file 1).

Clinical details were available for all 123 patients. Full clinical, laboratory, and outcome details are available in

Table 1 Clinical features and outcomes of the various urea cycle disorders

\begin{tabular}{|c|c|c|c|c|c|c|c|c|c|}
\hline Types of UCD & ASS1-D & ASL-D & OTC-D & ARG-D & CPS1-D & NAGS-D & Citrin-D & LPI & Total \\
\hline Total Numbers & 61 & 20 & 26 & 9 & 3 & 2 & 1 & 1 & 123 \\
\hline Consanguinity & $9(n=54)$ & $7(n=19)$ & $2(n=25)$ & $5(n=9)$ & $1(n=2)$ & $1(n=2)$ & $0(n=1)$ & $1(n=1)$ & $26(n=113)$ \\
\hline Positive family history & $14(n=56)$ & $9(n=20)$ & $12(n=24)$ & $2(n=9)$ & $0(n=3)$ & $1(n=1)$ & $0(n=1)$ & $0(n=1)$ & $38(n=115)$ \\
\hline \multicolumn{10}{|l|}{ Age group } \\
\hline Neonatal & 44 & 13 & 11 & 0 & 2 & 2 & 0 & 0 & 72 \\
\hline Infancy & 6 & 3 & 4 & 0 & 0 & 0 & 0 & 0 & 13 \\
\hline$>$ Infancy (> 1 year) & 11 & 4 & 11 & 9 & 1 & 0 & 1 & 1 & 38 \\
\hline \multicolumn{10}{|l|}{ Clinical presentation } \\
\hline $\begin{array}{l}\text { Neonatal or intermittent } \\
\text { encephalopathy, or seizures }\end{array}$ & 51 & 17 & 19 & 0 & 3 & 1 & 0 & 1 & 92 \\
\hline $\begin{array}{l}\text { Liver disease } \\
\text { (deranged liver enzymes) }\end{array}$ & 6 & 5 & 2 & 0 & 0 & 0 & 0 & 0 & 13 \\
\hline Failure to thrive & 3 & 1 & 1 & 1 & 0 & 0 & 0 & 1 & 7 \\
\hline Developmental delay & 6 & 5 & 7 & 9 & 0 & 0 & 0 & 0 & 27 \\
\hline $\begin{array}{l}\text { Other neuropsychiatric/ } \\
\text { behavioural/ ataxia/ spasticity } \\
\text { symptoms }\end{array}$ & Nil & 0 & 4 & 6 & 1 & 0 & 1 & 0 & 12 \\
\hline Mutations performed & 55 & 16 & 22 & 5 & 3 & 2 & 1 & 1 & 105 \\
\hline Results obtained & 55 & 15 & 18 & 5 & 3 & 2 & 1 & 1 & 100 \\
\hline \multicolumn{10}{|l|}{ Outcome } \\
\hline Death & 44 & 12 & 11 & 0 & 1 & 2 & 0 & 0 & 70 \\
\hline Alive & 10 & 5 & 14 & 8 & 1 & 0 & 1 & 1 & 40 \\
\hline Development: Delayed & 7 & 5 & 7 & 8 & 1 & 0 & 0 & 0 & 28 \\
\hline $\begin{array}{l}\text { Development: Normal or } \\
\text { near normal }\end{array}$ & 2 & 1 & 7 & 0 & 0 & 0 & 1 & 1 & 12 \\
\hline $\begin{array}{l}\text { Diet -Protein restriction+ } \\
\text { medications }\end{array}$ & 6 & 5 & 10 & 8 & 1 & 0 & 0 & 1 & 31 \\
\hline Lost to follow up/ not known & 7 & 3 & 1 & 1 & 1 & 0 & 0 & 0 & 13 \\
\hline
\end{tabular}


Additional file 1. Approximately three-fifth of patients $(72 / 123,58 \%)$ presented in the first 30 days of life (neonatal period), $88 \%$ of whom presented on or before day 7 of life (classical presentation). Thirteen cases presented in infancy between 1 and 12 months of life, and 38 after the first year of life. Overall male to female ratio was 1.7:1 (2.25:1 in OTC deficiency, 1.65:1 in non-OTC deficiency). Consanguinity and a positive family history were noted in $23 \%(26 / 113)$ and $33 \%(38 / 115)$ of families, respectively. All families were unrelated except one where a non-consanguineous couple visited our clinic after losing their daughter on day 6 of life with encephalopathy and no other investigations. Husband's niece was detected to have citrullinemia type 1 . Based on the history, the couple was tested and detected to be carriers of citrullinemia type 1. Apart from this, there were no related families.

Detailed description of all cases including demography, clinical presentations, family history, biochemical investigations, outcomes and prenatal diagnosis data (for subsequent pregnancies in parents of probands) are shown in Additional file 1: Table S1. A large number of cases presented with encephalopathy with or without seizures (94/ 123, 76\%), either in neonatal period or later (Table 1). Half of the patients in the late onset group presented with developmental delay $(22 / 51,43 \%)$. A significant number of children had features of liver disease (10.5\%) and failure to thrive (3\%) (Table 1).

\section{Outcome analysis}

Outcome data was available from 110 cases. Of these, 70 died and 12 patients are healthy and developing normally. The remaining 28 patients are surviving with varying degree of disability (Fig. 1 and Table 1).
Citrullinemia type 1 was the most frequently observed UCD and showed the worst outcome. Of 55 patients for whom outcome was known, 44 died (81.5\%), 7 children survived with disability ranging from minor learning difficulties to severe global delay and seizures, and 3 children survived without disability: 2 of whom received liver transplantation, and 1 patient with a milder presentation of neonatal cholestasis and liver dysfunction that resolved over time. All except 2 deaths occurred in the first episode of illness in neonatal period. In the two children who survived the initial insult in neonatal period, there was severe failure to thrive, and death because of relentless progression of disease with intercurrent illnesses.

Outcomes in ASL and OTC deficiency cases were also poor with a total mortality of 50\% (23/46 cases). In ASL deficiency survivors, all except 1 had some degree of disability. In OTC deficiency survivors, 5 of 8 girls and 2 of 6 boys have developmental delay and 3 girls and 4 boys were healthy (Table 1, Additional file 1: Table S1). All the children who are doing well presented with mild symptoms of episodic vomiting.

\section{Molecular genetic studies}

Molecular studies could be performed in 105 patients/families. All tests were targeted sequencing of genes based on preliminary biochemical diagnosis. Pathogenic or likely pathogenic variants were noted in 100 cases. Molecular analysis for specific genes did not reveal any pathogenic variant in 5 cases. Details of mutations are listed in Tables 2, 3 and 4 . Table 5 provides details of clinical presentation, and gene studies performed in mutation negative patients.

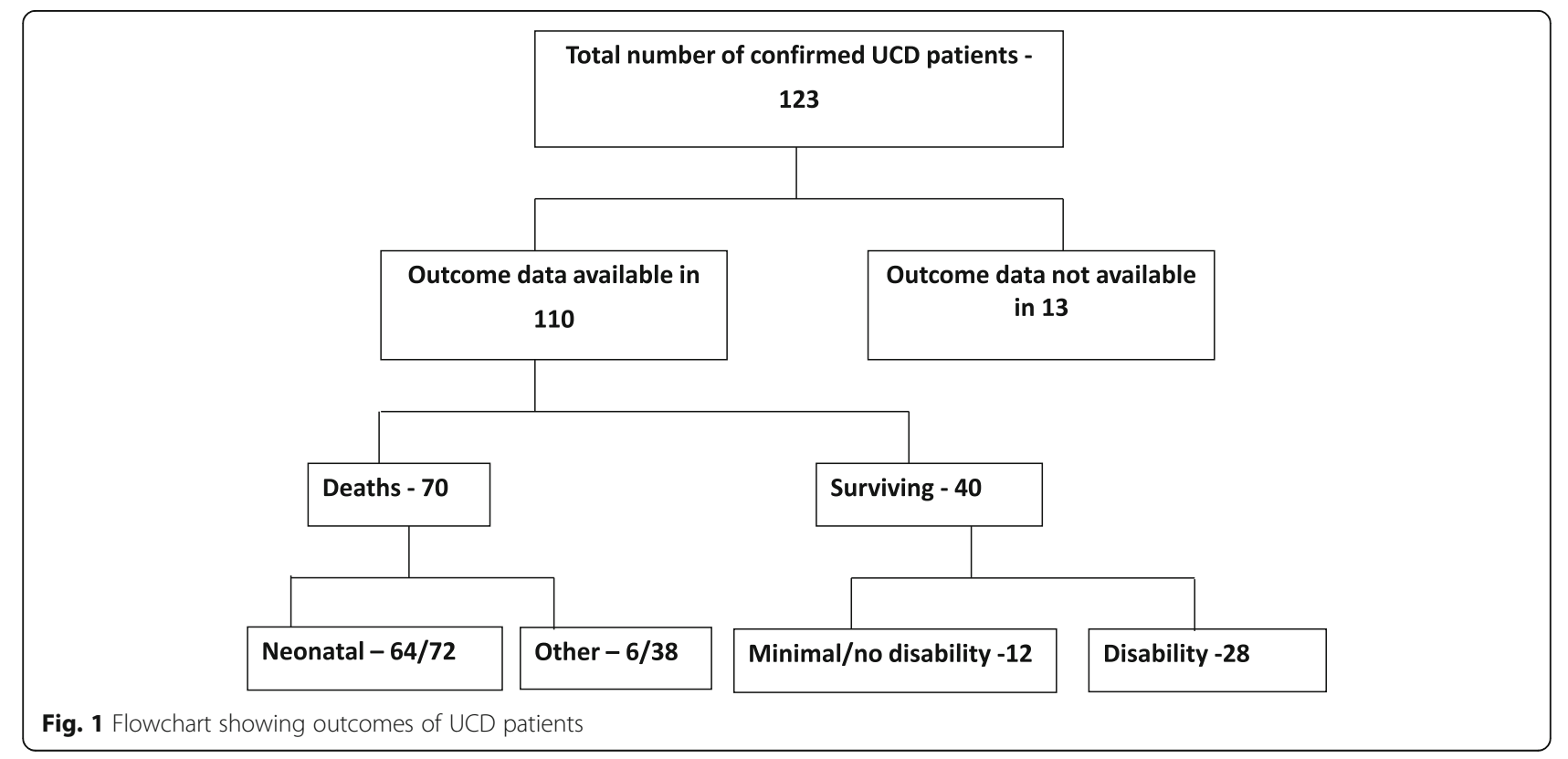


Table 2 Details of mutations in all patients

\begin{tabular}{|c|c|c|c|c|c|c|c|c|c|}
\hline \multirow[t]{2}{*}{ Gene } & \multicolumn{4}{|l|}{ Mutation } & \multicolumn{2}{|c|}{ Number of cases } & \multirow{2}{*}{$\begin{array}{l}\text { No. } \\
\text { of } \\
\text { alleles }\end{array}$} & \multirow[t]{2}{*}{ Reference } & \multirow{2}{*}{$\begin{array}{l}\text { ExAC data base } \\
\text { (allele frequency) }\end{array}$} \\
\hline & Position & DNA & Protein/ mRNA & Type & $\begin{array}{l}\text { Homo } \\
\text { zygous }\end{array}$ & $\begin{array}{l}\text { Hetero/ Hemi } \\
\text { zygous }\end{array}$ & & & \\
\hline \multirow[t]{17}{*}{ ASS1 } & Exon 5 & c. $190 G>A$ & p.Val64lle & Missense & 1 & 1 & 3 & Novel & 0.00003303 \\
\hline & Exon 5 & c. $269 \mathrm{G}>\mathrm{A}$ & p.Gly90Asp & Missense & 1 & 0 & 2 & Novel & NA \\
\hline & Exon 5 & c. $271 \mathrm{~A}>\mathrm{C}$ & p.Thr91Pro & Missense & 1 & 0 & 2 & Novel & 0.00003324 \\
\hline & Exon 5 & c. $299 \mathrm{G}>\mathrm{A}$ & p.Arg100His & Missense & 0 & 1 & 1 & {$[30]$} & 0.0001597 \\
\hline & Exon 5 & c.349G > T & p.Gly117Cys & Missense & 1 & 0 & 2 & [30] & NA \\
\hline & Exon 5 & c. $350 \mathrm{G}>\mathrm{A}$ & p.Gly117Asp & Missense & 0 & 1 & 1 & [36] & NA \\
\hline & Exon 6 & c. $370 \mathrm{G}>\mathrm{A}$ & p.Asp124Asn & Missense & 1 & 1 & 3 & [37] & NA \\
\hline & Exon 7 & $c .470 G>A$ & p.Arg157His & Missense & 12 & 1 & 25 & [38] & 0.00009932 \\
\hline & Exon 9 & C.570T > A & p.Tyr190Ter & PTC ${ }^{* *}$ & 0 & 1 & 1 & Novel & NA \\
\hline & Exon 12 & c. $793 C>T$ & p.Arg265Cys & Missense & 3 & 1 & 7 & [39] & 0.000008262 \\
\hline & Exon 12 & $c .815 G>A$ & p.Arg272His & Missense & 2 & 0 & 4 & {$[40]$} & NA \\
\hline & Exon 13 & C. $910 C>T$ & p.Arg304Trp & Missense & 2 & 0 & 4 & [38] & 0.00004119 \\
\hline & Exon 14 & $c .970 G>A$ & p.Gly324Ser & Missense & 1 & 0 & 2 & [38] & 0.00004952 \\
\hline & Exon 14 & c. $1088 \mathrm{G}>\mathrm{A}$ & p.Arg363Gln & Missense & 0 & 1 & 1 & {$[30]$} & 0.000008792 \\
\hline & Exon 15 & c.1139delA & p.Glu380Argfs*20 & $\begin{array}{l}\text { Deletion } \\
\text { sbp }^{*}\end{array}$ & 2 & 1 & 5 & Novel & NA \\
\hline & Exon 15 & C.1168G >C & p.Gly390Arg & Missense & 23 & 1 & 47 & [38] & NA \\
\hline & Total & & & & 50 & 10 & 110 & & \\
\hline \multirow[t]{17}{*}{ ASL } & Exon 3 & c.89_94delinsGTCGTA & p.Tyr30_Asp31delinsCysArg & DEL INS*** & 0 & 1 & 1 & Novel & NA \\
\hline & Exon 5 & c. $326 C>G$ & p.Thr109Arg & Missense & 0 & 1 & 1 & Novel & NA \\
\hline & Exon 5 & c.337C > T & p.Arg113Trp & Missense & 1 & 0 & 2 & [16] & 0.00006783 \\
\hline & Exon 7 & c. $509 \mathrm{G}>\mathrm{A}$ & p.Ser170Asn & Missense & 0 & 2 & 2 & [41] & NA \\
\hline & Exon 8 & c.593C > T & p.Pro198Leu & Missense & 1 & 0 & 2 & Novel & NA \\
\hline & Exon 9 & c. $637 \mathrm{C}>\mathrm{T}$ & p.Arg213Ter & PTC & 0 & 3 & 3 & {$[42]$} & 0.000008417 \\
\hline & Exon 9 & c. $649 \mathrm{C}>\mathrm{T}$ & p.Arg217Ter & PTC & 1 & 0 & 2 & Novel & 0.000008443 \\
\hline & Exon 11 & c. $733 \mathrm{~T}>\mathrm{C}$ & p.Trp245Arg & Missense & 0 & 1 & 1 & Novel & NA \\
\hline & Exon 11 & c.749T > A & p.Met250Lys & Missense & 0 & 1 & 1 & Novel & 0.00000854 \\
\hline & Exon 12 & $c .857 A>G$ & p.GIn286Arg & Missense & 2 & 1 & 5 & [43] & 0.00007499 \\
\hline & Exon 12 & $c .913 G>A$ & p.Gly305Arg & Missense & 0 & 1 & 1 & Novel & NA \\
\hline & Exon 12 & c. $967 A>G$ & p.Lys323Glu & Missense & 1 & 0 & 2 & Novel & NA \\
\hline & Exon 12 & $c .978 G>C$ & p.Gln326His & Missense & 0 & 1 & 1 & [41] & 0.00003771 \\
\hline & Exon 16 & c. $1153 C>T$ & p.Arg385Cys & Missense & 1 & 0 & 2 & [44] & 0.00006732 \\
\hline & Exon 17 & c. $1297 A>C$ & p.Ser433Arg & Missense & 0 & 2 & 2 & [41] & NA \\
\hline & Exon 17 & c.1300G > T & p.Val434Leu & Missense & 0 & 2 & 2 & [41] & 0.000008284 \\
\hline & Total & & & & 7 & 16 & 30 & & \\
\hline \multirow[t]{8}{*}{ OTC } & Exon 1 & c. $274 C>T$ & p.Arg92Ter & PTC & 0 & 1 & 1 & [45] & NA \\
\hline & Exon 1 & c. $275 \mathrm{G}>\mathrm{A}$ & p.Arg92Gln & Missense & 0 & 1 & 1 & {$[45]$} & NA \\
\hline & Exon 4 & c.386G > A & p.Arg129His & Missense & 0 & 3 & 3 & [32] & NA \\
\hline & Exon 5 & $c .421 C>T$ & p.Arg141Ter & PTC & 0 & 1 & 1 & [33] & NA \\
\hline & Exon 5 & c. $535 \mathrm{C}>\mathrm{T}$ & p.Leu179Phe & Missense & 0 & 1 & 1 & {$[46]$} & NA \\
\hline & Exon 6 & c. $604 C>T$ & p.His202Tyr & Missense & 0 & 1 & 1 & [47] & NA \\
\hline & Exon 7 & c. $674 C>T$ & p.Pro225Leu & Missense & 0 & 2 & 2 & [48] & NA \\
\hline & Exon 7-8 & c.773_790del & p.Asn258_263del & Deletion & 0 & 1 & 1 & Novel & NA \\
\hline
\end{tabular}


Table 2 Details of mutations in all patients (Continued)

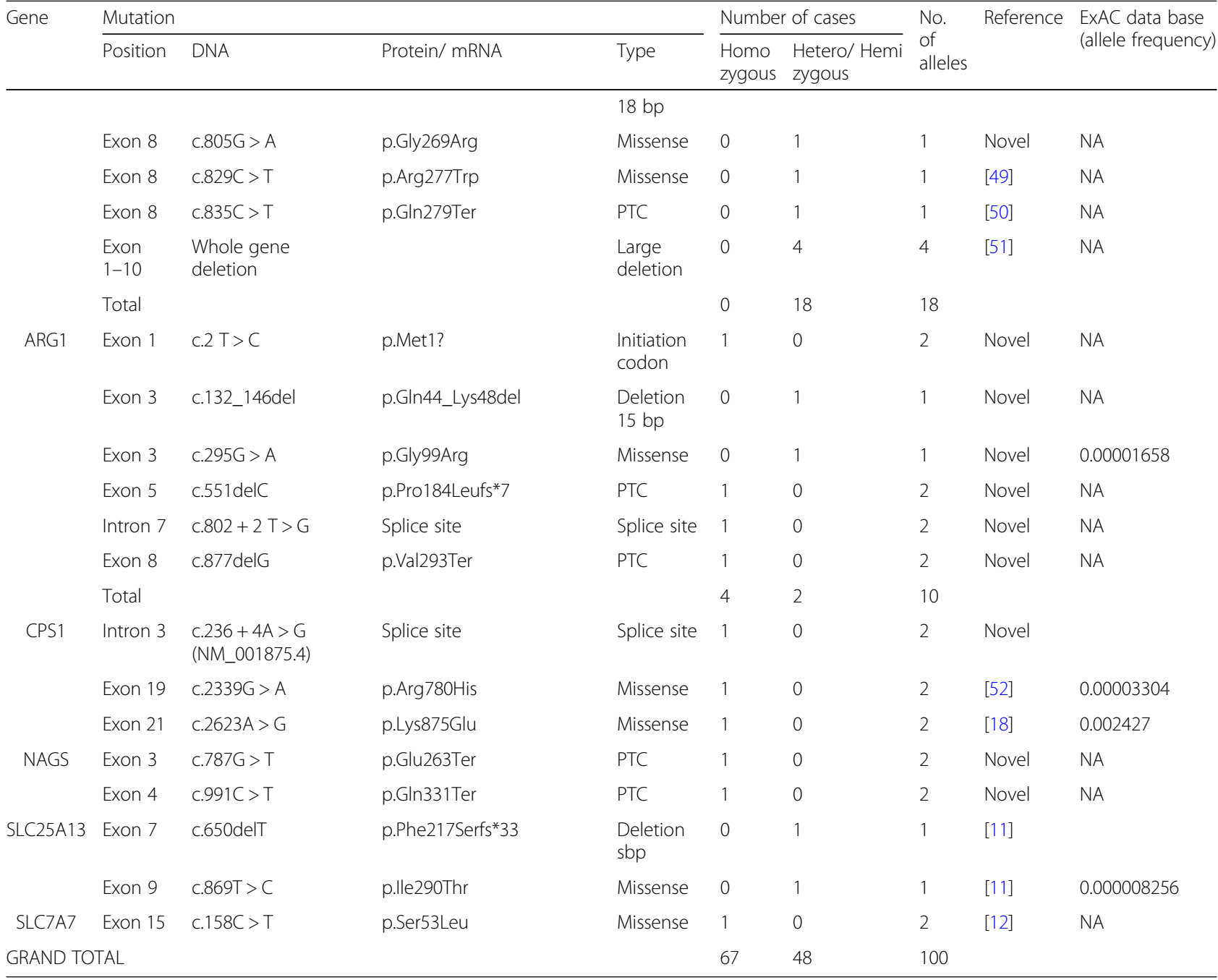

*sbp single base pair, ${ }^{* *}$ PTC Premature termination codon, ${ }^{* * *}$ DEL INS Deletion insertion

A total of 58 different mutations were detected in 100 patients, 16 of which were observed in ASS1 gene and $A S L$ gene each, 12 mutations in $O T C$ gene, and 6 mutations each in ARG1 gene, 3 in CPS1, 2 in NAGS and $S L C 25 A 13$ genes, and one in SLC7A7 gene (Table 2). Twenty four mutations were novel. Of 100 patients in whom the diagnosis was genetically confirmed, 67 were homozygous and 15 were compound heterozygous, 12 were hemizygous and 6 were heterozygous (for an $O T C$ mutation).

ASS1 gene sequencing was performed in 55 out of 61 cases. The two most common mutations, c.470G $>$ A (p.Arg157His) and c.1168G > A (p.Gly390Arg) were observed in 72 alleles out of a total of 110 alleles (65.5\%). The missense mutation, c.1168G > A occurred twice more frequently (47/110 alleles [42.7\%]) than c.470G > A (25/ 110 alleles [22.7\%]). Five mutations were novel (Table 3).

Sequencing of $A S L$ gene revealed more varied findings with 16 mutations in 15 cases. Interestingly, all mutations were in compound heterozygous states in the 8 cases from Centre 1 whereas all mutations were noted in homozygous form in the patients from Centre 2. Four mutations were noted to be recurrent: c.509G > A (p.Ser170Asn), c.637C > T (p.Arg213Ter), c.1297A > C (p.Ser433Arg) and c.1300G > T (p.Val434Leu), occurring in 2, 3, 2 and 2 alleles, respectively. Eight mutations were noted to be novel.

OTC gene sequencing was performed in 22 of 26 cases. No mutation was identified in 4 cases (one male, 2 female probands and 1 carrier mother) after full sequencing of OTC gene as well as MLPA analysis for deletions/duplications. The most common mutation noted was a whole gene deletion in 4 cases, accounting for $22.2 \%$ (4/18) cases. Rest of mutations were single nucleotide substitutions, missense or nonsense mutations. Pathogenic variants were also identified in arginase deficiency (5 cases), CPS1 deficiency (3 cases), two cases of NAGS deficiency, one case each citrin deficiency [10] and LPI [11]. All pathogenic variants in $A R G 1$ and NAGS genes were novel 
Table 3 Evaluation of pathogenicity of novel variants using in-silico prediction tools

\begin{tabular}{|c|c|c|c|c|c|c|c|c|c|}
\hline Gene & Mutation & Protein change & Mutation taster & LRT & SIFT & PROVEAN & DANN & EXAC & dbSNP \\
\hline \multirow[t]{5}{*}{ ASS1 } & C. $190 \mathrm{G}>\mathrm{A}$ & p.Val64lle & Disease causing & Neutral & Tolerated & Neutral & 0.9791 & 0.00003303 & $556,297,791$ \\
\hline & c. $269 \mathrm{G}>\mathrm{A}$ & p.Gly90Asp & Disease causing & Unknown & Damaging & Damaging & 0.9985 & Not Present & $1,422,867,920$ \\
\hline & c. $271 \mathrm{~A}>\mathrm{C}$ & p.Thr91Pro & Disease causing & Unknown & Damaging & Damaging & 0.9963 & 0.00003324 & $769,018,733$ \\
\hline & C. $570 \mathrm{C}>\mathrm{A}$ & p.Tyr190Ter & Disease causing & Unknown & NA & NA & 0.9957 & Not Present & Not Present \\
\hline & c.1139delA & p.Gln380Argfs*20 & Disease causing & NA & NA & NA & NA & Not Present & $1,213,378,896$ \\
\hline \multirow[t]{8}{*}{ ASL } & c.89_94delinsGTCGTA & p.Tyr30_Asp31delinsCysArg & Disease causing & NA & NA & NA & NA & Not present & Not present \\
\hline & c. $326 C>G$ & p.Thr109Arg & Disease causing & Deleterious & Damaging & Damaging & 0.9938 & Not present & Not Present \\
\hline & c. $593 \mathrm{C}>\mathrm{T}$ & p.Pro198Leu & Disease causing & Deleterious & Damaging & Damaging & 0.9992 & Not Present & $1,282,829,485$ \\
\hline & c. $649 \mathrm{C}>\mathrm{T}$ & p.Arg217Ter & Disease causing & Neutral & NA & NA & 0.9972 & 0.000008443 & $369,879,957$ \\
\hline & c.733T >C & p.Trp245Arg & Disease causing & Deleterious & Damaging & Damaging & 0.9941 & Not present & Not Present \\
\hline & c.749T > A & p.Met250Lys & Disease causing & Deleterious & Damaging & Damaging & 0.9791 & Not present & $754,634,171$ \\
\hline & c. $913 \mathrm{G}>\mathrm{A}$ & p.Gly305Arg & Disease causing & Deleterious & Damaging & Damaging & 0.9993 & Not present & Not Present \\
\hline & c. $967 A>G$ & p.Lys323Glu & Disease causing & Deleterious & Damaging & Damaging & 0.9987 & Not present & Not Present \\
\hline \multirow[t]{2}{*}{ OTC } & c.773_790del & p.Asn258_263Del & Disease causing & NA & NA & NA & NA & Not present & Not Present \\
\hline & C. $805 G>A$ & p.Gly269Arg & Disease causing & Deleterious & Damaging & Damaging & 0.9992 & Not Present & Not Present \\
\hline \multirow[t]{6}{*}{ ARG1 } & c. $2 \mathrm{~T}>\mathrm{C}$ & p.Met1Thr & Disease causing & Deleterious & Damaging & Neutral & 0.9809 & Not Present & Not Present \\
\hline & c.132_146del & p.Gln44_Lys48del & Disease causing & NA & NA & NA & NA & Not Present & Not Present \\
\hline & c. $295 \mathrm{G}>\mathrm{A}$ & p.Gly99Arg & Disease causing & Deleterious & Damaging & Damaging & 0.9993 & 0.00001658 & $753,829,097$ \\
\hline & c.551delC & p.Pro184Leufs*7 & Disease causing & NA & NA & NA & NA & Not Present & Not Present \\
\hline & $c .802+2 \mathrm{~T}>\mathrm{G}$ & Splice site & Disease causing & NA & NA & NA & 0.9948 & Not Present & Not Present \\
\hline & c.877delG & p.Val293Ter & Disease causing & NA & NA & NA & NA & Not Present & Not Present \\
\hline CPS1 & c. $254+4 A>G$ & Splice site & Disease causing & NA & NA & NA & 0.9747 & Not Present & Not Present \\
\hline \multirow[t]{2}{*}{ NAGS } & c.787G > T & p.Glu263Ter & Disease causing & Deleterious & NA & NA & 0.9963 & Not Present & Not Present \\
\hline & c.991C > T & p.Gln331Ter & Disease causing & Deleterious & NA & NA & 0.9973 & Not Present & $1,445,639,047$ \\
\hline
\end{tabular}

Mutation Taster: An in silico prediction tool for the pathogenicity of a variant based on evolutionary conservation, splice-site, mRNA, protein and regulatory features. The potential is predicted by a naive Bayes classifier

LRT: Likelihood ratio test (LRT) predicts deleterious variants through identification of highly conserved amino acid regions using a comparative genomics data set of 32 vertebrate species. Range 0 to 1

SIFT: SIFT (sorts intolerant from tolerant) is an in silico prediction tool for nonsynonymous variants based on sequence homology derived from closely related sequences collected through PSI-BLAST. Range 0 to 1 with values less than 0.05 usually considered intolerant. $40 \%$ of the values in this database are below 0.01

PROVEAN: Protein Variation Effect Analyzer is an in silico tool that predicts how nonsynonymous, MNP, or in-frame indel variant will affect a protein's biological function. The prediction is based on alignment-based scores derived from pairwise sequence alignments between the query sequence and each of the related sequences at the protein level. Range -14 to +14

DANN: DANN is a pathogenicity scoring methodology developed by Daniel Quang, Yifei Chen and Xiaohui Xie at the University of California, Irvine. It is based on deep neural networks. The value range is 0 to 1 , with 1 given to the variants predicted to be the most damaging

(Tables 2 and 3). Another novel pathogenic variant was noted in CPS1 gene. The pathogenicity of this variant, c. $236+4 \mathrm{~A}>\mathrm{G}$ (NM_001875.4) was checked via RNA studies at Zurich. On RNA level, as a consequence of this splice-site mutation, two alternatively spliced transcript variants were observed: the majority of transcripts showed complete skipping of exon 2 (r.127_236del, p.Ala43Valfs*7) but also partial skipping of exon 2 (r.206_236del, p.Glu70Thrfs"70) was observed. Both parents are carriers of the mutation, confirming obligate heterozygosity.

\section{Prenatal diagnosis}

Mutation analysis led to successful prenatal diagnoses in 30 pregnancies in 25 families (Table 6). This included one couple that opted for pre-implantation genetic diagnosis (PGD) after having an affected fetus in a preceding pregnancy. In this case the result was normal, and the couple delivered a healthy baby. Of the 29 prenatal analyses, 11 pregnancies were found to carry fetuses with no mutation (normal), 13 with carrier fetuses (including 2 OTC female carriers, both of whom are doing well after birth) and 5 carried affected fetuses. Amongst 19 pregnancies in families with ASS or ASL deficiency, 4 pregnancies were found to have fetuses affected with disease (21\%).

\section{Discussion}

Urea cycle disorders occur universally with varying frequencies in different populations [1,21-23]. While OTC 
Table 4 Types of mutations detected

\begin{tabular}{ll}
\hline Total number of patients with mutations & 100 \\
\hline Number of patients with homozygous mutations & 67 \\
Total number of mutations & 58 \\
Total number of novel mutations & 24 \\
Missense mutations & 39 \\
Premature termination codon & 10 \\
Initiation codon mutation & 1 \\
Splice site mutation & 2 \\
Small insertions/ deletions & 5 \\
Large deletion & 1 \\
\hline
\end{tabular}

deficiency has been reported to be the most commonly occurring UCD, citrullinemia type 1 is reported to be less common [3, 5, 24]. In contrast, in our cohort, citrullinemia type 1 contributed to about half $(61 / 123,49.6 \%)$, thus making citrullinemia type 1 the most commonly occurring UCD in this cohort. The data was pooled from two centres, both showing similar results independently. OTC deficiency was observed with lower frequency in the cohort. In fact, the total incidence for OTC deficiency was less than half of that found for citrullinemia type 1. Although suspected in few additional patients (hyperammonemia with high urinary orotic acid expected in OTC deficiency), there was insufficient evidence to prove OTC deficiency in some patients because of the difficulty in performing enzyme based diagnosis (which would have required a liver biopsy) or due to lack of mutations in the OTC gene despite full gene study (sequencing as well as testing for larger deletions and duplications by MLPA). These difficulties are however well known and described earlier in large studies [25]. Many factors contributed to the failure to achieve a definitive diagnosis in all patients: the lack of availability of enzyme diagnostics at any centre in India, the invasiveness of the test (liver biopsy) along with difficulty in shipment of liver biopsy specimens in frozen state to another centre abroad, and the overall cost involved. It is therefore likely that cases of OTC deficiency are being missed in India, as known from literature [25].

The situation is different in the case of citrullinemia type 1 , where a very high citrulline level on dried blood spot MS/MS can be reliably detected leading to further gene studies confirming the diagnosis. Presence of ASA in blood or urine is indicative of ASL deficiency, and for elevated plasma arginine of arginase deficiency.

Urea cycle disorder commoner than OTC deficiency has also been noted in Saudi Arabian population, where ASL deficiency has been described as the most common UCD. Consanguinity in this particular population seems to be one leading explanation [26]. Parallels can be drawn with the Indian population where both consanguinity and closed community marriages are the norm, leading to genetic isolates. This may be a part explanation to citrullinemia type 1 being more common in India. In our cohort, consanguinity was noted in $23 \%$ families. Consanguinity and close community marriages are important factors leading to increased occurrence of recessive disorders, at least in India [27].

Table 5 Patients in whom molecular studies showed no mutations

\begin{tabular}{|c|c|c|c|c|c|c|c|c|c|}
\hline $\begin{array}{l}\text { Gene } \\
\text { studied }\end{array}$ & $\begin{array}{l}\text { S.No } \\
\text { (as in } \\
\text { Additional } \\
\text { file 1) }\end{array}$ & $\begin{array}{l}\text { Age at } \\
\text { presentation }\end{array}$ & $\begin{array}{l}\text { Sex } \\
\text { (proband) }\end{array}$ & Consanguinity & $\begin{array}{l}\text { Family } \\
\text { history } \\
\text { of similar } \\
\text { disease }\end{array}$ & $\begin{array}{l}\text { Clinical features } \\
\text { in proband }\end{array}$ & $\begin{array}{l}\text { Amino acids levels } \\
\text { by MS/MS on dried } \\
\text { blood spot ( } \mu \mathrm{mol} / \mathrm{l})\end{array}$ & GC-MS in urine & $\begin{array}{l}\text { Ammonia } \\
\text { level } \\
\text { (in } \mu \mathrm{mol} / \mathrm{l} \text { ) }\end{array}$ \\
\hline$\overline{A S L}$ & 78 & 4 days & Male & No & No & $\begin{array}{l}\text { Neonatal } \\
\text { encephalopathy, } \\
\text { convulsions, } \\
\text { lethargy, reduced } \\
\text { feeding }\end{array}$ & $\begin{array}{l}\text { Citrulline- } 2557 \\
\text { ASA- } 753.19\end{array}$ & $\begin{array}{l}\text { Increased } \\
\text { orotate } 393\end{array}$ & NK \\
\hline \multirow[t]{4}{*}{ OTC } & 86 & 4 days & Male & No & $\begin{array}{l}\text { Yes, } \\
\text { previous } \\
2\end{array}$ & $\begin{array}{l}\text { Neonatal } \\
\text { encephalopathy } \\
\text { and deaths }\end{array}$ & NK & $\begin{array}{l}\text { Allopurinol } \\
\text { challenge test in } \\
\text { mother - increase } \\
\text { in orotate }\end{array}$ & NK \\
\hline & 93 & 5 days & Male & No & Yes & $\begin{array}{l}\text { Neonatal } \\
\text { encephalopathy } \\
\text { and death }\end{array}$ & NK & Increased orotate & High \\
\hline & 96 & 2 years & Female & No & $\begin{array}{l}\text { Yes, } \\
\text { elder } \\
\text { sister }\end{array}$ & $\begin{array}{l}\text { Encephalopathy, } \\
\text { Febrile illness with } \\
\text { high ammonia }\end{array}$ & $\begin{array}{l}\text { Normal amino acid } \\
\text { levels Citrulline } 15, \\
\text { arginine } 15, \\
\text { ornithine } 146\end{array}$ & Increased orotate & High 1600 \\
\hline & 98 & 1.5 years & Female & No & No & $\begin{array}{l}\text { Encephalopathy, } \\
\text { Vomiting, awkward } \\
\text { behaviour, high } \\
\text { ammonia }\end{array}$ & NK & Increased orotate & Level NK \\
\hline
\end{tabular}


Table 6 Prenatal diagnosis in families with UCDs

\begin{tabular}{|c|c|c|c|c|c|c|c|}
\hline $\begin{array}{l}\text { S. No (as per } \\
\text { Additional file 1) }\end{array}$ & $\begin{array}{l}\text { Diagnosis } \\
\text { in proband }\end{array}$ & $\begin{array}{l}\text { Age at presentation } \\
\text { in probands }\end{array}$ & $\begin{array}{l}\text { Consanguinity } \\
\text { among parents }\end{array}$ & $\begin{array}{l}\text { Mutations } \\
\text { in proband }\end{array}$ & Protein change & $\begin{array}{l}\text { Number } \\
\text { of PND }\end{array}$ & Results of PND \\
\hline 5 & ASS1-D & 6 days & No & c.1168G > A & p.Gly390Arg & Once & Not affected (carrier) \\
\hline 7 & ASS1-D & 5 days & Yes & c. $470 \mathrm{G}>\mathrm{A}$ & p.Arg157His & Twice & $\begin{array}{l}\text { One affected, one } \\
\text { unaffected (carrier) }\end{array}$ \\
\hline 10 & ASS1-D & 5 days & No & c.1168G > A & p.Gly390Arg & Once & Not affected \\
\hline 16 & ASS1-D & 7 days & No & $\begin{array}{l}c .570 T>A \\
c .350 G>A\end{array}$ & $\begin{array}{l}\text { p.Tyr190Ter \& } \\
\text { p.Gly117Asp }\end{array}$ & Once & Affected \\
\hline 17 & ASS1-D & 4 days & No & c.1139delA & $\begin{array}{l}\text { p.Glu380Arg } \\
f^{*} 20\end{array}$ & Once & Not affected (carrier) \\
\hline 18 & ASS1-D & 4 days & No & c. $470 G>A$ & p.Arg157His & $\begin{array}{l}\text { Once, } \\
\text { one PGD }\end{array}$ & $\begin{array}{l}\text { Affected, PGD pregnancy } \\
\text { healthy baby }\end{array}$ \\
\hline 19 & ASS1-D & 6 days & Yes & $c .970 G>A$ & p.Gly324Ser & Once & Not affected (carrier) \\
\hline 22 & ASS1-D & 2 days & Yes & $c .470 G>A$ & p.Arg157His & Once & Not affected (carrier) \\
\hline 27 & ASS1-D & 4 days & No & c.1168G > A & p.Gly390Arg & Once & Not affected \\
\hline 30 & ASS1-D & 5 days & No & $c .470 G>A$ & p.Arg157His & Once & Not affected (carrier) \\
\hline 33 & ASS1-D & 3 days & No & c.1168G > A & p.Gly390Arg & Once & Not affected \\
\hline 35 & ASS1-D & Neonatal & No & C.1168G > A & p.Gly390Arg & Once & Not affected \\
\hline 61 & ASS1-D & Neonatal & No & c. $1168 \mathrm{G}>\mathrm{A}$ & p.Gly390Arg & Once & Not affected (carrier) \\
\hline 62 & ASL-D & 4 days & No & $\begin{array}{l}\text { C. } 509 \mathrm{G}>\mathrm{A} \\
\text { C. } 1297 \mathrm{~A}>\mathrm{C}\end{array}$ & $\begin{array}{l}\text { p.Ser170Asn } \\
\text { p.Ser433Arg }\end{array}$ & Twice & $\begin{array}{l}\text { Affected once, not } \\
\text { affected second time }\end{array}$ \\
\hline 65 & ASL-D & 5 days & No & $\begin{array}{l}\text { C. } 637 \mathrm{C}>\mathrm{T} \\
\text { C. } 1300 \mathrm{G}>\mathrm{T}\end{array}$ & $\begin{array}{l}\text { p.Arg213Ter } \\
\text { p.Val434Leu }\end{array}$ & Once & Not affected (carrier) \\
\hline 70 & ASL-D & 9 days & Yes & $\begin{array}{l}\text { C. } 913 \mathrm{G}>\mathrm{A} \\
\mathrm{c.} .749 \mathrm{~T}>\mathrm{A}\end{array}$ & $\begin{array}{l}\text { p.Gly305Arg } \\
\text { p.Met250Lys }\end{array}$ & Once & Not affected (carrier) \\
\hline 87 & OTC-D & 6 days & No & c. $674 C>T$ & p.Pro225Leu & Twice & $\begin{array}{l}\text { Not affected (once } \\
\text { carrier, once no mutation) }\end{array}$ \\
\hline 91 & OTC-D & 3 days & Yes & \multicolumn{2}{|c|}{$\begin{array}{l}\text { whole gene deletion } \\
\text { (mother tested) }\end{array}$} & Once & Carrier female \\
\hline 92 & OTC-D & 3 days & No & c. $274 \mathrm{C}>\mathrm{T}$ & p.Arg92Ter & Once & Not affected \\
\hline 94 & OTC-D & 5 days & Yes & c. $421 \mathrm{C}>\mathrm{T}$ & p.Arg141Ter & Twice & $\begin{array}{l}\text { First affected male, } \\
\text { second carrier female }\end{array}$ \\
\hline 97 & OTC-D & 2 days & No & \multicolumn{2}{|c|}{$\begin{array}{l}\text { whole gene deletion } \\
\text { (mother tested) }\end{array}$} & Once & Not affected \\
\hline 101 & OTC-D & 5 years & No & \multicolumn{2}{|c|}{$\begin{array}{l}\text { whole gene deletion } \\
\text { (mother tested) }\end{array}$} & Once & Not affected \\
\hline 119 & CPS1 -D & NK & NK & c. $2623 A>G$ & p.Lys875Glu & Once & Not affected \\
\hline 120 & NAGS-D & NK & NK & c. $991 C>T$ & p.GIn331Ter & Once & Not affected \\
\hline 121 & NAGS-D & Neonatal & Yes & c.787G > T & p.Glu263Ter & Once & Not affected (Carrier) \\
\hline
\end{tabular}

NK: Not known, PGD: Pre-implantation genetic diagnosis

In our study, 10 couples (and 6 expectant mothers in case of OTC deficiency) were tested in absence of a sample from index patient, and their gene study detected heterozygous mutations, suggesting an accurate diagnosis in their probands. In seven couples, citrullinemia type 1 was suspected based on elevated plasma citrulline in index patient and these couples were only tested for mutations in ASS1 gene.

The presentation in most Indian children was similar to what is known in literature, with both neonatal classic form and late onset presentations. In our cohort, the neonatal classic presentation was more common in all UCDs except arginase and citrin deficiency. This finding is somewhat different from other studies where majority of presentations are beyond first 30 days of life $[1,28,29]$. The more common early presentation in our cohort may have been a bias because neonatal cases are recognized more easily in view of a careful medical supervision in the neonatal period. A recent study from Europe reported 50 patients of UCD detected both symptomatically (39/50) and NBS/presymptomatically (11/50). In this cohort, 28 of 39 symptomatically detected patients presented with neonatal encephalopathy, 
thus corroborating with our observation of a neonatal presentation being more common [5]. The high mortality among the neonatal encephalopathy group in our cohort was similar to the cohort reported from Europe [5].

A family history of previous sibling deaths was present in approximately $33 \%$ of families. This highlights the immense burden of the disease on the families, and the ignorance as well as lack of facilities denying these families of an opportunity for early diagnosis and prompt treatment. This would have prevented the suffering, either by successful treatment of the index child or by prenatal diagnosis. Molecular diagnosis thus helped the families in prevention of recurrence of this difficult group of disorders.

Molecular analysis revealed several interesting findings besides being immensely helpful in family counseling. For ASS1 gene, there were two common mutations, p.Gly390Arg and p.Arg157His which constituted 65.5\% of cases. These two are previously reported mutations and are present globally [30]. Most common mutation seen in multiple ethnic group is p.Gly390Arg except in the east Asian population where another mutation, c.421-2A > G is the commonest [31]. Another mutation, p.Arg265Cys seen in our population was common to the Japanese population [31]. There seemed to be a good genotype-phenotype correlation, which is in agreement with reported literature [24]. Two recurring mutations, p.Arg213Ter and p.Ser170Asn, were found in $A S L$ gene.

In a significant number of OTC deficiency patients, a whole gene deletion was detected. In this disorder, whole gene deletions as well as nonsense mutations were noted either in neonatally presenting severely affected males or in manifesting females, while missense mutations were noted in mildly affected boys. This finding is also in agreement with literature [21, 32, 33]. The mutation p.Arg129His, showing a mild phenotype with excellent prognosis, has previously been described [34]. Similarly, p.Arg277Trp is known to be a mild mutation, reported even in male transmission [35].

Molecular analysis enabled successful prenatal diagnosis in 30 pregnancies with no false negative results. This is an effective way of reducing the disease-related morbidity and mortality, until appropriate facilities are made available for early diagnosis and treatment.

\section{Conclusions}

This is the first comprehensive report of mutations in UCDs from the Indian subcontinent. Increasing availability of gene sequencing has enabled higher numbers of prenatal diagnosis for UCDs. Establishing a precise molecular diagnosis by mutation analysis is helpful not only for accurate genetic counseling but also for accurate carrier testing, which is an efficient way for reducing the morbidity and mortality associated with the disease through prenatal diagnosis.

\section{Additional file}

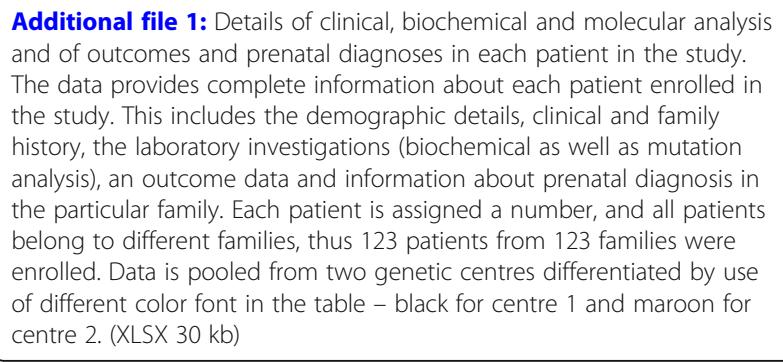

\section{Abbreviations}

ARG: Arginase; ASL: Argininosuccinate Lyase; ASS1: Argininosuccinate Synthetase 1; CPS1: Carbamoyl phosphate synthetase 1; GCMS: Gas chromatography mass spectrometry; HPLC: High performance liquid chromatography; ICU: Intensive Care Units; MS/MS: Mass spectrometry, mass spectrometry/ Tandem mass spectrometry; NAGS: N-acetyl glutamate synthase; OTC: Ornithine Transcarbamylase; UCD: Urea cycle disorders

\section{Acknowledgements}

The authors acknowledge the valuable contributions from all the collaborators and referring physicians for patients and/or samples. Mutation analysis at University Children's Hospital Zurich was supported by the Swiss National Science Foundation (grant 310030_153196 to JH). We duly acknowledge the support of all our patients and their families, and staff members, especially Mr. Kuldeep Singh, Dr. Divya Thomas, Dr. Sanjeev Pandey, Dr. Divya Agarwal, Dr. Moni Tuteja, Dr. Udhaya Kotecha, Dr. Pratima Dash, Dr. Sangeeta Khatter, Dr. Vinu N, Dr. Kanika Singh, Dr. Vibha Jain, Ms. Achint Kaur, Mr. Naresh Kashyap, Mr. Rajendra Mishra and others at the Institute of Medical Genetics \& Genomics at SGRH. We also acknowledge the contribution by way of referring patients and samples from our collaborators all over India, especially Dr. Madhulika Kabra \& Dr. Neerja Gupta (AllMS, New Delhi), Dr. Seema Kapoor (MAMC, New Delhi), Dr. Sujatha Jagadeesh \& Dr. Solomon F D Paul (Chennai), Dr. Meenakshi Bhat (Bangalore), Dr. Balakrishnan (Kerala), Dr. Amandeep Raj (Delhi), Dr. Shubha Phadke (SGPGI, Lucknow), Dr. Neelam Mohan (Gurgaon), Dr. Ashish Sahani \& Dr. Rohit (Delhi), Dr. Rajeev Bansal and Dr. Vivek Jain (Jaipur), Dr. Saurabh Chopra (Delhi) and others without whose support the study wouldn't have been possible. We acknowledge the contribution of Dr. Namrata Singh and team from Turacoz Healthcare Solutions for editing the manuscript specifically for language and syntax.

\section{Funding}

Partial funding was availed from the Swiss National Science Foundation (grant 310030_153196 to JH).

\section{Availability of data and materials}

The data collected was from two centres where patients were managed for the particular genetic disorder.

\section{Authors' contributions}

SBM and $J H$ contributed to design of study and manuscript writing. SBM, RDP, $A B J$, ICV were involved in clinical management of patients. JH, KK, SK, RS, DG, DM were involved in molecular testing of patients and their parents. JV, SY and YS contributed to biochemical analysis and prenatal diagnosis of patients. JH, SK, RS, DG and DM contributed to prenatal diagnosis of patients. ICV and JH contributed to critically analyzing the manuscript and providing important intellectual contents. All authors read and approved the final manuscript.

\section{Ethics approval and consent to participate} Not applicable.

\section{Consent for publication}

Consent has been taken from all the authors. No individual patient data including videos, voice recordings or images have been submitted for publication. 


\section{Competing interests}

The authors declare that they have no competing interests.

\section{Publisher's Note}

Springer Nature remains neutral with regard to jurisdictional claims in published maps and institutional affiliations.

\section{Author details}

${ }^{1}$ Institute of Medical Genetics and Genomics, Sir Ganga Ram Hospital, New Delhi, India. 'University Children's Hospital Zurich and Children's Research Centre, Steinwiesstr 75, CH-8032 Zurich, Switzerland. ${ }^{3}$ Navi Mumbai Institute of Research In Mental And Neurological Handicap (NIRMAN), Navi Mumbai, India. ${ }^{4}$ Department of Pediatrics, Faculty of Medical Science, University of Fukui, Fukui, Japan. ${ }^{5}$ Department of Pediatrics, Shimane University Faculty of Medicine, 89-1 En-ya-cho Izumo, Shimane 693-8501, Japan.

Received: 21 February 2018 Accepted: 12 September 2018

Published online: 01 October 2018

\section{References}

1. Häberle J, Boddaert N, Burlina A, Chakrapani A, Dixon M, Huemer M, Karall D, Martinelli D, Sanjurjo Crespo P, Santer R, Servais A, Valayannopoulos V, Lindner M, Rubio V, Dionisi-Vici C. Suggested guidelines for the diagnosis and management of urea cycle disorders. Orphanet J Rare Dis. 2012;7:32.

2. Brusilow SW, Maestri NE. Urea cycle disorders: diagnosis, pathophysiology, and therapy. Adv Pediatr Infect Dis. 1996;43:127-70.

3. Summar ML, Koelker S, Freedenberg D, Le Mons C, Haberle J, Lee HS, Kirmse B. European registry and network for intoxication type metabolic diseases (E-IMD). Electronic address: http://www.e-imd.org/en/index.phtml; members of the urea cycle disorders consortium (UCDC). Electronic address: http://rarediseasesnetwork.epi.usf.edu/ucdc/. The incidence of urea cycle disorders. Mol Genet Metab. 2013;110:179-80.

4. Wilcken B, Haas M, Joy P, Wiley V, Bowling F, Carpenter K, Christodoulou J, Cowley D, Ellaway C, Fletcher J, Kirk EP, Lewis B, McGill J, Peters H, Pitt J, Ranieri E, Yaplito-Lee J, Boneh A. Expanded newborn screening: outcome in screened and unscreened patients at age 6 years. Pediatrics. 2009;124:e241-8.

5. Nettesheim S, Kölker S, Karall D, Häberle J, Posset R, Hoffmann GF, HeinrichB GF, Garbade SF, Arbeitsgemeinschaft für Pädiatrische Stoffwechselstörungen (APS); European registry and network for Intoxication type Metabolic Diseases (E-IMD); Erhebungseinheit für Seltene PädiatrischeErkrankungen in Deutschland (ESPED); Austrian Metabolic Group; Swiss Paediatric Surveillance Unit (SPSU). Incidence, disease onset and short-term outcome in urea cycle disorders -cross-border surveillance in Germany, Austria and Switzerland. Orphanet J Rare Dis. 2017:12(1):111.

6. Unsinn C, Das A, Valayannopoulos V, Thimm E, Beblo S, Burlina A, Konstantopoulou V, Mayorandan S, de Lonlay P, Rennecke J, Derbinski J, Hoffmann GF, Häberle J. Clinical course of 63 patients with neonatal onset urea cycle disorders in the years 2001-2013. Orphanet J Rare Dis. 2016;11:116.

7. Nassogne MC, Héron B, Touati G, Rabier D, Saudubray JM. Urea cycle defects: management and outcome. J Inherit Metab Dis. 2005;28:407-14.

8. Picca S, Dionisi-Vici C, Abeni D, Pastore A, Rizzo C, Orzalesi M, Sabetta G, Rizzoni G, Bartuli A. Extracorporeal dialysis in neonatal hyperammonemia: modalities and prognostic indicators. Pediatr Nephrol. 2001;16:862-7.

9. Gupta N, Kabra M, Häberle J. Mutation analysis of Indian patients with urea cycle defects. Indian Pediatr. 2012;49:585-6.

10. Karthikeyan $\mathrm{G}$, Jagadeesh $\mathrm{S}$, Seshadri S, Häberle J. Citrullinemia type 1: genetic diagnosis and prenatal diagnosis in subsequent pregnancy. Indian Pediatr. 2013;50:965-6.

11. Bijarnia-Mahay S, Häberle J, Rüfenacht V, Shigematsu Y, Saxena R, Verma IC. Citrin deficiency: a treatable cause of acute psychosis in adults. Neurol India. 2015;63:220-2

12. Bijarnia-Mahay S, Jain V, Bansal RK, Reddy GM, Häberle J. Lysinuric protein intolerance presenting with recurrent Hyperammonemic encephalopathy. Indian Pediatr. 2016;53:732-4.

13. Adzhubei IA, Schmidt S, Peshkin L, Ramensky VE, Gerasimova A, Bork P, Kondrashov AS, Sunyaev SR. A method and server for predicting damaging missense mutations. Nat Methods. 2010;7:248-9.

14. Schwartz JM, Cooper DN, Schuelke M, Seelow D. MutationTaster2: mutation prediction for the deep-sequencing age. Nat Methods. 2014;11:361-2.
15. Kumar P, Henikoff S, Ng PC. Predicting the effects of coding nonsynonymous variants on protein function using the SIFT algorithm. Nat Protoc. 2009;4:1073-81.

16. Linnebank M, Tschiedel E, Häberle J, Linnebank A, Willenbring H, Kleijer WJ, Koch HG. Argininosuccinate lyase (ASL) deficiency: mutation analysis in 27 patients and a completed structure of the human ASL gene. Hum Genet. 2002;111:350-9.

17. Häberle J, Koch HG. Genetic approach to prenatal diagnosis in urea cycle defects. Prenat Diagn. 2004;24:378-83.

18. Häberle J, Pauli S, Linnebank M, Kleijer WJ, Bakker HD, Wanders RJ, Harms E, Koch $\mathrm{HG}$. Structure of the human argininosuccinate synthetase gene and an improved system for molecular diagnostics in patients with classical and mild citrullinemia. Hum Genet. 2002:110:327-33.

19. Häberle J, Shchelochkov OA, Wang J, Katsonis P, Hall L, Reiss S, Eeds A, Willis A, Yadav M, Summar S, Urea Cycle Disorders Consortium, Lichtarge O, Rubio V, Wong LJ, Summar M. Molecular defects in human carbamoyl phosphate synthetase I: mutational spectrum, diagnostic and protein structure considerations. Hum Mutat. 2011;32:579-89.

20. Kretz R, Hu L, Wettstein V, Leiteritz D, Häberle J. Phytohemagglutinin stimulation of lymphocytes improves mutation analysis of carbamoylphosphatesynthetase 1. Mol Genet Metab. 2012;106(3):375-8.

21. Engel K, Höhne W, Häberle J. Mutations and polymorphisms in the human arginino-succinate synthetase (ASS1) gene. Hum Mutat. 2009;30:300-7.

22. Laróvere LE, Angaroni CJ, Antonozzi SL, Bezard MB, Shimohama M, de Kremer RD. Citrullinemia type I, classical variant. Identification of ASS-p. G390R (c.1168G\&gt;A) mutation in families of a limited geographic area of Argentina: a possible population cluster. Clin Biochem. 2009;42:1166-8.

23. Sokoro AA, Lepage J, Antonishyn N, McDonald R, Rockman-Greenberg C, Irvine J, Lehotay DC. Diagnosis and high incidence of hyperornithinemiahyperammonemia-homocitrullinemia $(\mathrm{HHH})$ syndrome in northern Saskatchewan. J Inherit Metab Dis. 2010;33(Suppl 3):275-81.

24. Quinonez SC, Thoene JG. Citrullinemia Type I. 2004 Jul 7 [Updated 2016 Sep 1]. In: Adam MP, Ardinger HH, Pagon RA, et al., editors. GeneReviews ${ }^{\circledast}$ [Internet]. Seattle (WA): University of Washington, Seattle; 1993-2018. Available from: https://www.ncbi.nlm.nih.gov/books/NBK1458/.

25. Yamaguchi S, Brailey LL, Morizono H, Bale AE, Tuchman M. Mutations and polymorphisms in the human ornithine transcarbamylase (OTC) gene. Hum Mutat. 2006;27:626-32

26. Imtiaz F, Al-Sayed M, Trabzuni D, Al-Mubarak BR, Alsmadi O, Rashed MS, Meyer BF. Novel mutations underlying argininosuccinic aciduria in Saudi Arabia. BMC Res Notes. 2010;3:79. https://doi.org/10.1186/17560500-3-79.

27. Gupta D, Bijarnia-Mahay S, Saxena R, Kohli S, Dua-Puri R, Verma J Thomas E, Shigematsu Y, Yamaguchi S, Deb R, Verma IC. Identification of mutations, genotype phenotype correlation and prenatal diagnosis of maple syrup urine disease in Indian patients. Eur J Med Genet. 2015;58:471-8.

28. Keskinen P, Siitonen A, Salo M. Hereditary urea cycle diseases in Finland Acta Paediatr. 2008;97:1412-9.

29. Summar ML, Dobbelaere D, Brusilow S, Lee B. Diagnosis, symptoms, frequency and mortality of 260 patients with urea cycle disorders from a 21-year, multi-Centre study of acute hyperammonaemic episodes. Acta Paediatr. 2008;97:1420-5.

30. Gao HZ, Kobayashi K, Tabata A, Tsuge H, lijima M, Yasuda T, Kalkanoglu HS, Dursun A, Tokatli A, Coskun T, Trefz FK, Skladal D, Mandel H, Seidel J, Kodama S, Shirane S, Ichida T, Makino S, Yoshino M, Kang JH, Mizuquchi M, Barshop BA Fuchinoue S, Seneca S, Zeesman S, Knerr I, Rodés M, Wasant P, Yoshida I, De Meirleir L, Abdul Jalil M, Begum L, Horiuchi M, Katunuma N, Nakagawa S, Saheki T. Identification of 16 novel mutations in the argininosuccinate synthetase gene and genotype-phenotype correlation in 38 classical citrullinemia patients. Hum Mutat. 2003;22:24-34

31. Woo HI, Park HD, Lee YW. Molecular genetics of citrullinemia types I and II. Clin Chim Acta. 2014;431:1-8.

32. Tuchman M, Plante RJ, McCann MT, Qureshi AA. Seven new mutations in the human ornithine transcarbamylase gene. Hum Mutat. 1994:4:57-60.

33. Hata A, Setoyama C, Shimada K, Takeda E, Kuroda Y, Akaboshi I, Matsuda I. Ornithine transcarbamylase deficiency resulting from a C-to-T substitution in exon 5 of the ornithine transcarbamylase gene. Am J Hum Genet. 1989;45: $123-7$.

34. García-Pérez MA, Sanjurjo P, Rubio V. Demonstration of the spf-ash mutation in Spanish patients with ornithine transcarbamylase deficiency of moderate severity. Hum Genet. 1995;95(2):183-6. 
35. Numata S, Koda Y, Ihara K, Sawada T, Okano Y, Matsuura T, Endo F, Yoo HW, Arranz JA, Rubio V, Wermuth B, Ah Mew N, Tuchman M, Pinner JR, Kirk EP Yoshino M. Mutant alleles associated with late-onset ornithine transcarbamylase deficiency in male patients have recurrently arisen and have been retained in some populations. J Hum Genet. 2010;55(1):18-22.

36. Vilaseca MA, Kobayashi K, Briones P, Lambruschini N, Campistol J, Tabata A, Alomar A, Rodès M, Lluch M, Saheki T. Phenotype and genotype heterogeneity in Mediterranean citrullinemia. Mol Genet Metab. 2001;74:396-8.

37. Kleijer WJ, Garritsen VH, van der Sterre ML, Berning C, Häberle J, Huijmans $J G$. Prenatal diagnosis of citrullinemia and argininosuccinic aciduria: evidence for a transmission ratio distortion in citrullinemia. Prenat Diagn 2006;26:242-7.

38. Kobayashi K, Jackson MJ, Tick DB, O'Brien WE, Beaudet AL. Heterogeneity of mutations in argininosuccinate synthetase causing human citrullinemia. J Biol Chem. 1990:265:11361-7.

39. Berning C, Bieger I, Pauli S, Vermeulen T, Vogl T, Rummel T, Höhne W, Koch HG, Rolinski B, Gempel K, Häberle J. Investigation of citrullinemia type I variants by in vitro expression studies. Hum Mutat. 2008;29:1222-7.

40. Dimmock DP, Trapane P, Feigenbaum A, Keegan CE, Cederbaum S, Gibson J, Gambello MJ, Vaux K, Ward P, Rice GM, Wolff JA, O'Brien WE, Fang P. The role of molecular testing and enzyme analysis in the management of hypomorphic citrullinemia. Am J Med Genet A. 2008; 146A:2885-90.

41. Balmer C, Pandey AV, Rüfenacht V, Nuoffer JM, Fang P, Wong L, Häberle J. Mutations and polymorphisms in the human argininosuccinate lyase (ASL) gene. Hum Mutat. 2014:35:27-35.

42. Trevisson E, Salviati L, Baldoin MC, Toldo I, Casarin A, Sacconi S, Cesaro L, Basso G, Burlina AB. Argininosuccinate lyase deficiency: mutational spectrum in Italian patients and identification of a novel ASL pseudogene. Hum Mutat. 2007;28:694-702.

43. Walker DC, McCloskey DA, Simard LR, McInnes RR. Molecular analysis of human argininosuccinate lyase: mutant characterization and alternative splicing of the coding region. Proc Natl Acad Sci U S A. 1990;87:9625-9.

44. Kleijer WJ, Garritsen VH, Linnebank M, Mooyer P, Huijmans JG, Mustonen A, Simola KO, Arslan-Kirchner M, Battini R, Briones P, Cardo E, Mandel H, Tschiedel E, Wanders RJ, Koch HG. Clinical, enzymatic, and molecular genetic characterization of a biochemical variant type of argininosuccinic aciduria: prenatal and postnatal diagnosis in five unrelated families. J Inherit Metab Dis. 2002;25:399-410.

45. Grompe M, Caskey CT, Fenwick RG. Improved molecular diagnostics for ornithine transcarbamylase deficiency. Am J Hum Genet. 1991;48:212-22.

46. Arranz JA, Riudor E, Marco-Marín C, Rubio V. Estimation of the total number of disease-causing mutations in ornithine transcarbamylase (OTC) deficiency. Value of the OTC structure in predicting a mutation pathogenic potential. J Inherit Metab Dis. 2007;30:217-26.

47. Tuchman M, Morizono H, Rajagopal BS, Plante RJ, Allewell NM. Identification of 'private' mutations in patients with ornithine transcarbamylase deficiency J Inherit Metab Dis. 1997;20:525-7.

48. Hentzen D, Pelet A, Feldman D, Rabier D, Berthelot J, Munnich A. Fatal hyperammonemia resulting from a C-to-T mutation at a Mspl site of the ornithine transcarbamylase gene. Hum Genet. 1991;88:153-6.

49. Finkelstein JE, Francomano CA, Brusilow SW, Traystman MD. Use of denaturing gradient gel electrophoresis for detection of mutation and prospective diagnosis in late onset ornithine transcarbamylase deficiency. Genomics. 1990;7:167-72.

50. Tuchman M, Jaleel N, Morizono H, Sheehy L, Lynch MG. Mutations and polymorphisms in the human ornithine transcarbamylase gene. Hum Mutat. 2002;19:93-107.

51. Brassier A, Gobin S, Arnoux JB, Valayannopoulos V, Habarou F, Kossorotoff M, Servais A, Barbier V, Dubois S, Touati G, Barouki R, Lesage F, Dupic L, Bonnefont JP, Ottolenghi C, De Lonlay P. Long-term outcomes in ornithine Transcarbamylase deficiency: a series of 90 patients. Orphanet J Rare Dis. 2015;10:58.

52. Kurokawa K, Yorifuji T, Kawai M, Momoi T, Nagasaka H, Takayanagi M, Kobayashi K, Yoshino M, Kosho T, Adachi M, Otsuka H, Yamamoto S, Murata T, Suenaga A, Ishii T, Terada K, Shimura N, Kiwaki K, Shintaku H, Yamakawa M, Nakabayashi H, Wakutani Y, Nakahata T. Molecular and clinical analyses of Japanese patients with carbamoylphosphate synthetase 1 (CPS1) deficiency. J Hum Genet. 2007;52:349-54.

\section{Ready to submit your research? Choose BMC and benefit from:}

- fast, convenient online submission

- thorough peer review by experienced researchers in your field

- rapid publication on acceptance

- support for research data, including large and complex data types

- gold Open Access which fosters wider collaboration and increased citations

- maximum visibility for your research: over $100 \mathrm{M}$ website views per year

At BMC, research is always in progress.

Learn more biomedcentral.com/submissions 